\title{
PHILOLOGY
}

\section{THE FUNCTIONAL FEATURES OF POLYSEMY IN ENGLISH AND UZBEK LANGUAGES}

\author{
PhD student Nargiza Masharipova \\ Uzbekistan, Urgench, Urgench State University
}

DOI: https://doi.org/10.31435/rsglobal_ijitss/28022020/6949

\section{ARTICLE INFO}

Received 17 December 2019

Accepted 23 February 2020

Published 28 February 2020

\section{KEYWORDS}

polysemy, linear relations, non-linear relations, metaphor, metonymy, systematic polysemy.

\begin{abstract}
In fact, the emotive potential of the language is high and polysemy is a great advantage to a language, so the article illustrates the varieties of polysemy, structural and functional features of polysemy in translation, differences between the usage and classification of polysemy in Uzbek and English languages. The paper deals with also the problems of translation of polysemy in both languages by using comparative and contrastive analysis of observation.
\end{abstract}

Citation: Nargiza Masharipova. (2020) The Functional Features of Polysemy in English and Uzbek Languages. International Journal of Innovative Technologies in Social Science. 2(23). doi: 10.31435/rsglobal_ijitss/28022020/6949

Copyright: (C) 2020 Nargiza Masharipova. This is an open-access article distributed under the terms of the Creative Commons Attribution License (CC BY). The use, distribution or reproduction in other forums is permitted, provided the original author(s) or licensor are credited and that the original publication in this journal is cited, in accordance with accepted academic practice. No use, distribution or reproduction is permitted which does not comply with these terms.

Introduction. It is mostly stated that a polysemy is the ability of a word to possess several meanings or lexico-semantic variants (LSV), usually related by contiguity of meaning within a semantic field. Hurford defines polysemy this way: a case of polysemy is one where a word has several very closely related senses. In other words, native speaker of the language has clear intuitions that in different senses are related to each other in some way. Example: "mouth" mouth of a person and a mouth of river, here they both mean "an opening of from the interior of some solid mass to the outside". If one consider the varieties of polysemy, it is known that polysemous senses have motivated relationship among each another. There are different ways to sort out these relations. For example, according to D. Alan Cruse's point of view, we can differentiate two relations: linear (or vertical) and non-linear relations between polysemes [1, 110-111]. These relations have also their subgroups that are illustrated below in the graph:

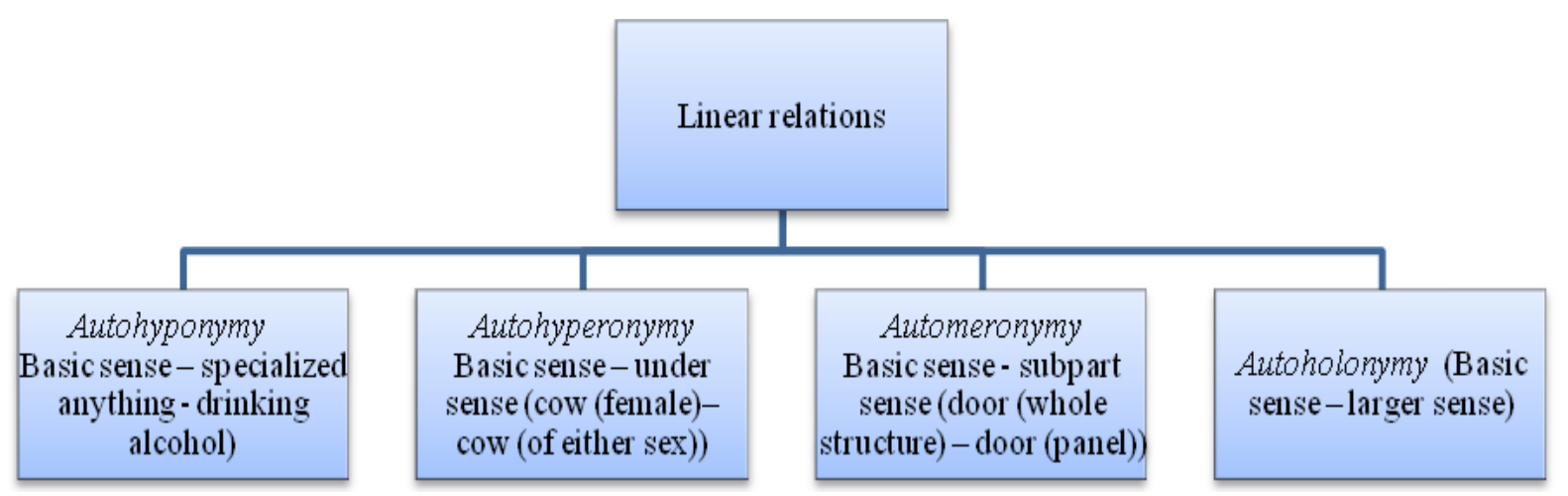

Fig. 1. Linear relations between polysemous senses 
Senses have a linear relation if one is a specialization of the other (which of course entails that the latter is a generalization of the former). We can distinguish specialization from generalization if we recognize one of the senses as more basic than the other: if $\mathrm{A}$ is more basic than $\mathrm{B}$, and $\mathrm{B}$ is more specialized than $\mathrm{A}$, then $\mathrm{B}$ is a specialization of $\mathrm{A}[1,110]$.

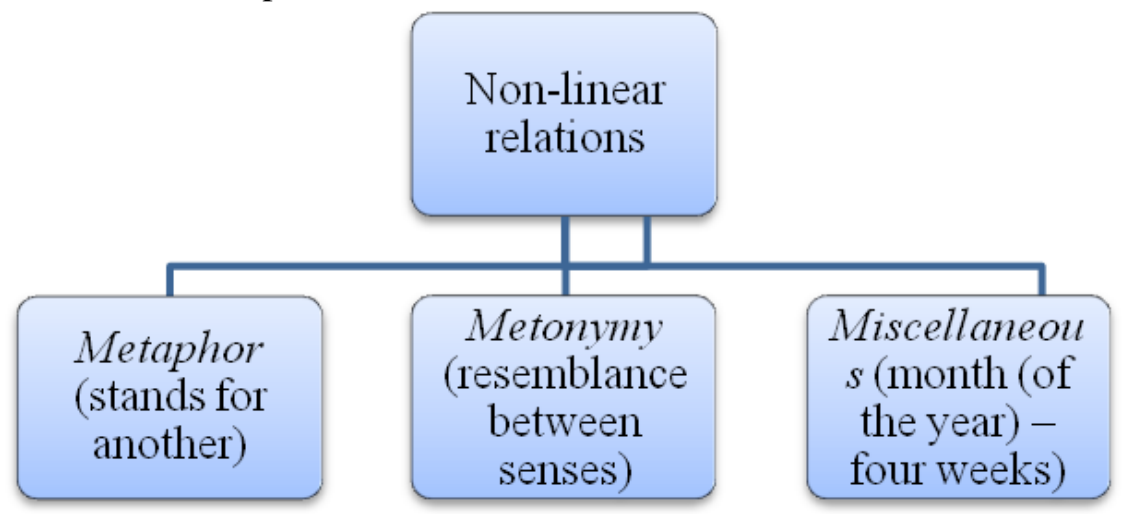

Fig. 2. Non-linear relations between polysemous senses

The need to justify the differences of meaning postulated within a polysemous lexeme is a general requirement on any semantic theory, but it is especially pressing for any conceptualist interpretation of metaphor and metonymy, such as the one characteristic of 'standard' cognitive linguistics $[2,116]$.

Metaphor is based on the affinity or interplay of two meanings of a word - direct and contextual and its usage will be analyzed as follows:

- "Besides Della has beautiful golden hair", here the word combination "golden hair" means the girls hair is beautiful or the colour of her hair is looks like a golden. And in this sentence, author expresses the meaning by the word "golden" itself.

There are other examples like this:

- "It reached below her knees and covered her like a cloak";

- "The next two hours were like a happy dream".

In the third sentence "dream" is described by "happy" and here its meaning changes to contextual meaning rather than the usage of direct one, if we translate it into Uzbek, we may see the differences also:

- "So'nggi ikki soat xuddi shirin tush kabi o'tdi".

In the sentence, we translate "happy" into Uzbek like "shirin", and we have observed that the meaning also changes metaphorically while translating the combination into second language. While translating metaphor we should pay attention three aspects of metaphor, they are demonstrated below:

a) the aspect of the degree of expressiveness;

b) the aspect of the structure of polysemous senses;

c) the aspect of the function of polysemous senses.

We can see the samples of the usage of metaphor in the Uzbek language itself:

- "Endi "J" ga keldingizmi?" - dedi san'atkor jahli chiqib. (A. Kahhor).

- "Niso buvi qizlari tufayli necha marta qo'ydi-chiqdi bo'lib qoldi”. (A. Kahhor).

- "Usta Abdurahmon ko'pdan beri Niso buviga: "Mehrini Faxriddinga qilamiz", - deb yurar edi". (A. Kahhor).

Metonymy is characterized as figurative use based on association and considered as a rich source of polysemous variation. As well as, in Uzbek there are also these kinds of features of polysemantic words and the words change its meaning according to the context with different words. Metonymical examples are given below in Uzbek are similar when we translate them into English:

- Ko'p og'izni boqishim kerak. There are too many mouths to feed.

Og'zingni to'latib gapirma. Don't talk with your mouth full.

- Bu ajoyib yubka ekan. That's a nice bit of skirt. U qizil yubka kiygan edi. She wore a red skirt.

- Jonning o'z mashinasi bor. John has his own wheels. G'ildiraklardan biri tushib ketdi. One of the wheels fell off.

- Jeyn "kattakon"ga turmushga chiqdi. Jane married a large bank account. Jeynning bank hisob raqami bor. Jane has a bank account. 
As we can see that, some sentences are translated also metonymically into Uzbek, while some others are translated by using different word but not changing the meaning of the context, here are the examples of metonymical words in the Uzbek language:

- Juvon xodimlarga qaradi va so'radi: "Shu mahallalikmisizlar?"

- Anavi mo'ylov kim?

- Qalam orqasidan ro'zg'or tebratyapti.

- Uning og'zini yopdi (jim qildi).

We can see the metonymically translation into English in those sentences:

- The woman looked at the staff and asked: "Are you in this neighborhood?"

- Who is the moustache? (Who is the man?)

- He is living by the pen. (by writing)

- She kept his mouth shut.

Research results. As it was stated the lexical meaning is different from and more concrete and individual than other meanings. Each lexical meaning belongs to certain word. Developing the meaning of the word causes to widen its lexical meaning, also. And the words will become polysemantic. It means that the language doesn't create a new name for each new notion and meaning, but they can be expressed by exist words in the language. As a result, the lexico-semantic meaning will widen. For example, the verb "uchmoq" (to fly), in fact, is connected to the action of birds, but nowadays the meaning is widening and the verb is connected with the notions like "eye", "kite", "plane", "artificial satellite of the earth". In the first sight, there are similarities between homonyms and polysemantic words. Both of them have the same form, but the meaning is different. But there are big differences between these words. The matter is that, the meanings of polysemantic words are connected or similar to each other, because polysemantic words are formed by widening the dominant meaning of one word, and although the notion in the basic meaning expresses another notion, there are commonality the things or events that they express. For instance, "bet" (face) is polysemantic, because it is used in the meanings of "man's face", "the face of the street", "the face of the book". We can see that, there are similarities of their meanings. In Russian, there are five meanings of the word "baza", in English, there are more than ten meanings of the word "get", so there is the difference between homonymy and polysemy in the draft $[3,112]$ :

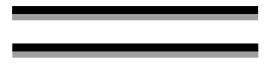

(homonymy)

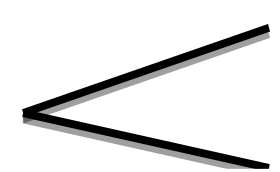

(polysemy)

We will analyze the features of polysemantic words by comparing examples of Uzbek and English polysemantic words with the examples taken from the stories by O'Henry. e.g.

"golden hair" - "Besides Della has beautiful golden hair". The word "golden" means: a) having a bright yellow color like gold; b) a golden opportunity - a good chance to get something valuable or to be very successful; c) golden boy/girl - someone who is popular and successful; d) a golden period of time is one of great happiness or success: golden years, golden days. As you can see, there are many meanings of "golden" whereas an author used the word to describe a woman's hair. In Uzbek language, a word "oltin" (tilla) has various meanings like "oltin soch", "oltin kalit", "tilla bola", "tilla fikr" and we can also use the word "oltin" to describe like this, and translate the sentence into Uzbek with an equivalent: "Shuningdek, Dellaning tillarang sochlari bor". The structure of this word is formed by a derivative word "tilla+rang".

"shone brilliantly" - "Her eyes shone brilliantly". Brilliantly adv (of brilliant): a) bright - brilliant light or color is very bright and strong; b) clever - extremely clever and skillful. In Uzbek: "olmos" - a) olmos (qimmatbaho tosh); b) yorug', yorqin; c) aqlli; d) mukammal. And in the sentence in Uzbek it can be translated by the usage of the word "olmos" (diamond) in order to give the correct meaning of the sentence: "Uning ko'zlari charaqlab ketdi” yoki "Uning ko'zlari olmosdek chaqnab ketdi”.

Systematic polysemy. Due to the little pressure for systematicity in the nature of metaphor, it is considered as the least systematic one. And the most basic ones are probably the most systematic metaphors, many of which are so naturalized that they hardly feel like metaphors any more $[1,113]$. According to Murphy, regular (also called systematic) polysemy is a variety of polysemy that gets a fair amount of linguistic attention [4, 89-90]. For example, words for containers can generally refer to both kind of container and the contents of the container, as can described below: 
- "container" sense: I put some sand into a box/bottle/tin/canister.

- "contents" sense: I dumped the whole box/bottle/tin/canister onto the floor.

Metonymy can be highly systematic, and Cruse gives some subtypes of it and his classification is similar to Putejevskiy's: "tree species" / "type of wood"; "fruit" / "tree species"; "flower" / "plant"; "animal" / "meat"; "composer" / "music by same"; "food" / "person ordering same". Here are some examples can be defined:

- Beethoven was deaf (composer). Bethoven kar bo'lgan.

- Do you like Beethoven? (music by same). Bethovenni yoqtirasanmi? (Bethovenning asarlarini tinglashni yoqtirasanmi?)

- I have been reading Navoi for a long time (a work by an author). Navoiyni anchadan beri o'qib yuribman.

Conclusions. The study of polysemy is, of course, based on the intrinsic nature of the languages and each language has its specific features in the field. Whereas, a more comprehensive study of peculiarities of the phenomenon like polysemy, the ability of words to have more than one meaning, can give a broader atmosphere and a good chance for an in-depth analysis of similar and various features of different systematic languages.

\section{REFERENCES}

1. Cruse, D. A. Meaning in Language. An Introduction to Semantics and Pragmatics. University of Manchester: Oxford University Press. 2000.

2. Riemer, N. Cognitive Linguistics Research. The Semantics of Polysemy: Reading Meaning in English and Warlpiri. Walter de Gruyter GmbH \& Co. KG, D-10785, Germany: Berlin, 2005.

3. Irisqulov, M. T. Tilshunoslikka kirish. Second ed. Tashkent: Yangi asr avlodi, 2009.

4. Murphy, M.L. Lexical Meaning. United Kingdom: Cambridge University Press, 2010.

5. Lyons, J. Linguistic Semantics. UK: Cambridge University Press, 1995.

6. Lyons, J. Introduction to theoretical linguistics. UK: Cambridge University Press, 1968.

7. Bolinger, D., \& Sears, D. A. Aspects of language (3rd ed.). NewYork: Harcourt Brace Jovanovich, 1981.

8. Whitehurst, G. J. Meaning and semantics. In G. J. Whitehurst \& B. J. Zimmerman (Eds.), The functions of language and cognition. New York: Academic Press, 1979.

9. Riegel, K. F., \& Riegel, R. M. An investigation into denotative aspects of word meaning. Language and Speech, 6, 5-21, 1963.

10. Evens, M. W., Litowitz, B.E., Markowitz, J. A., Smith, R. N., \& Werner, O. Lexical-semantic relations: A comparative survey (Current Inquiry into Language and Linguistics No. 34). Carbondale, IL, and Edmonton, Ontario, Canada: Linguistic Research, Inc., 1980. 